\title{
RADA'AH DALAM PERSPEKTIF FILOSOFIS, NORMATIF, YURIDIS, PSIKOLOGIS, SOSIOLOGIS, EKONOMIS
}

\author{
Suryani* \\ Abstract
}

Radaah is a breastfeeding of children or babies delivered to other women who are not mothers, resulting in mahram law between breastfeeding mothers and their children with their breastfed children. Radaah is permitted by Islam, according to the aqad or agreement between the child's parents and the woman who breastfed her. Culturally, then in Indonesia is not there, because even if parents can not breastfeed their children for something, then the alternative taken is to give their children with formula milk. The Radaah is commonly done by the Arabs.

Kata Kunci: rada'ah, perspektif, penyusuan anak.

\section{Pendahuluan}

Anak adalah anugrah Allah kepada kedua orang tua, oleh karena itu orang tua bertanggung jawab atas pertumbuhan dan perkembangan anaknya. Orang tua dituntut untuk memperhatikan perkembangan anaknya dengan tujuan untuk mengungkap karasteriktik setiap fase perkembangan anak, baik ditinjau dari fisik, kejiwaan (psikologis), emosional dan kemampuan intelektual.

Fase-fase perkembangan anak meliputi, fase menyusui (radha' $a h$ ), fase usia dua sampai pada tiga tahun (fase hadhanah), fase usia tiga sampai tujuh tahun (fase tamyiz), fase akil baligh (bulugh), fase remaja dan dewasa (fase syayab), fase masa tua (syaikhukhah). ${ }^{1}$ Pada fase radha'ah (menyusui) seorang anak (bayi) secara praktis hanya mengandalkan asupan air susu ibu (ASI). Berawal dari seorang bayi lahir sampai umur dua tahun seorang anak membutuhkan ASI tersebut. Dalam al-Qur'anpun dijelaskan bahwa masa menyusukan anak itu adalah dua tahun. $^{2}$ Dalam Islam pemberian Asi kepada anak ditegaska sebagaimana dalam ayat di atas adalah dua tahun, baik disusui oleh ibunya atau oleh orang lain. Menyususui anak secara kodrati merupakan salah satu bagian dalam siklus seorang perempuan, namun pada kenyataannnya ada saja seorang perempuan yang tidak menyusui anaknya sendiri dikarenakan berbagai faktor, ${ }^{3}$ oleh karena itu ketika seorang perempuan tidak dapat/bisa menyusui anaknya sendiri, maka anak tersebut dalam islam diperbolehkan untuk menyusu dengan perempuan lain, yang nanti pada akhirnya membawa implikasi terhadap haramnya pernikahan karena persusuan yang disebut denga radha'ah.

\section{Radaah Ditinjau dari Aspek Filosofis}

Secara ontologis Rada'ah berasal dari kata rada'ah, yardha'u, irdha', 
radhatan yang berarti penyusuan/menyusi. ${ }^{4}$ Secara Etimologis (Bahasa) radha'ah berarti sebuah isapan susu, baik isapan susu manusia maupun susu binatang. ${ }^{5}$ Secara terminologi radha'ah berarti sampainya (masuknya) air susu manusia (perempuan) selain ibu kandung ke dalam perut anak (bayi) yang belum berusia dua tahun atau 24 bulan. ${ }^{6}$ Radhaah memiliki akibat hukum dalam Islam, yakni terjadinya hubungan mahram antara anak yang disusui (radhi') dengan ibu yang menyusui murdhi' ah serta anak-anak dari ibu yang menyusui.

Secara efistimologi rada' ah atau menyusui adalah kewajiban bagi seorang ibu, karena itu merupakan tanggung jawab seorang ibu kepada anaknya yang akan ditanya di hadapan Allah baik perempuan tersebut masih menjadi isteri ayah dari bayi maupun sudah bercerai dan selesai masa iddahnya. Adanya rada'ah itu sendiri banyak perbedaan pendapat tentang kebolehan dan keharusan menyususi bagi seorang ibu. Perbedaan pendapat ini bersumber dari cara memahami ayat Q.S: al-Baqoroh: 233 :

Artinya:

"Dan ibu-ibu hendaklah menyusui anaknya selama dua tahun penuh, bagi yang ingin menyusui secara sempurna. Dan kewajiban ayah menanggung nafkah dan pakaian mereka dengan cara yang patut.
Seseorang tidak dibabani lebih dari kesangupannya. Janganlah seorang ibu menderita karena anaknya dan jangan pula seorang ayah (menderita) karena anaknya. Ahli warispun berkewajiban seperti itu pula. Apabila keduanya ingin menyapih dengan persetujuan dan permusyawaratan antara keduanya, maka tidak ada dosa atas keduanya. Dan jika kamu ingin menyusukan anak kamu kepada orang lain, maka tidak ada dosa bagimu memberikan pembayaran dengan cara yang patut. Bertakwalah kepada Allah dan ketehuilah bahwa Allah Maha Melihat apa yang kamu kerjakan".

Banyak faktor yang membuat mengapa terjadinya rada' $a h$ atau persusuan ini, ada karena air asi dari ibu seorang bayi tidak ada (tidak keluar), ibu bayi meninggal, ibu bayi tidak dapat menyusui bayinya sendiri karena suatu penyakit yang menular atau tidak memungkinkannya untuk menyusui bayinya sendiri, anak atau bayi tidak dapat menerima susu si ibu atau anak tidak mau menerima susu si ibu, ibu bayi tidak dapat menyusui bayinya karena harus berpisah dengan bayinya karena berpergian jauh yang mengharuskannnya untuk mencari nafkah 
yang tidak memungkinkan dia membawa bayinya, seorang ibu yang memang tidak mau menyusui bayinya karena dikhawatirkan akan mempengaruhi kecantikannya. Oleh karena itu ditentukanlah syarat dan rukun rada'ah tersebut.

Syarat dan rukun radha'ah atau penyusuan adalah: ${ }^{7}$

Syarat Rada'ah:

a. Adanya susu manusia (permpuan yang menyusui)/

b. Air susu itu masuk ke dalam perut bayi

c. Bayi belum berumur dua tahun. Rukun Radh'ah:
a. Anak yang disusui
b. Perempuan yang menyusui
c. Kadar air susu

Secara aksiologis radha'ah bertujuan untuk kelangsungan hidup seorang anak atau bayi, kebaikan si anak dan merealisasikan kewajiban dari orang tua, baik itu ayah ataupun ibu. Ibu berkewajiban untuk menyusui anaknya, sementara seorang ayah berkewajiban untuk menanggung nafkah isteri dan anaknya secara layak. Namun dalam keadaan tertentu, maka seorang ibu boleh menyewa perempuan lain untuk menyusui anaknya dengan kesepakatan dan pembayaran yang telah ditentukan bersama.
Menyusui anak merupakan hak seorang ibu, dan hak anak untuk disusui, oleh karena itu dianjurkan seorang ibu untuk menyusui anaknya. Anjuran ini terdapat dalam Q.S. al-Thalaq: 6, Anjuran dalam pemahaman ayat di atas menurut mayoritas 'ulama' mengatakan bahwa sifatnya sunnah, yang dilakukan oleh ibu kandungnya, namun bila anak tidak mau menerima susuan selain ibunya maka, seorang ibu wajib menyusukan anaknya. Da tiga hal yang menjadikan seorang ibu hukumnya wajib menyusukan anaknya, ${ }^{8}$ yaitu:

1. Si anak tidak menerima susuan orang lain selain ibu kandungnya, maka wajib hukumnya menyusui anaknya, demikian juga perempuan yang menyusui dengan imbalan, jika memang si anak tidak menerima susuan orang lain selain dirinya.

2. Tidak menemukan perempuan lain yang menyusui anaknya selain dirinya sendiri.

3. Jika suami atau si bayi tidak mempunyai harta untuk biaya sewa perempuan yang mau menyusui anak tersebut.

Dengan demikian dapat dipahami bahwa boleh menyususkan anak kepada perempuan lain, kecuali dalam tiga hal di atas, dengan upah menurut kesepakatan, demikian juga isteri yang telah dicerai suaminya, dan habis masa iddah. 
Tinjauan Rada'ah Secara Normatif dan Yuridis

Dalam al-Qur'an surat al-Nisa': 23 dinyatakan bahwa saudara sepersusuan itu adalah setiap orang yang disusui oleh seorang ibu yang sama. ${ }^{9}$ Begitu jua ditegaskan dalam hadis Nabi, 10 bahwa sepersusuan mengharamkan apa yang diharamkan karena garis keturunan. Sebagaimana dalam riwayat Nabi tentang anak perempuan Hamzah, ${ }^{11}$ Nabi mengatakan ia (anak Hamzah), tidak halal bagiku, karena diharamkan dari sepersusuan sebagaimana diharamkan kerena nasab, ia adalah saudara perempuan sepersusuanku.

Dari dalil dan keterangan di atas dapat dipahami bahwa wanita yang menyusui seseorang menjadi berkedudukan sebagai ibu kandung yang disusuinya, mereka diharamkan menikahi saudara sepersusuan karena saudara sepersusuan itu termasuk dalam jenis-jenis diharamkan menikahinnya kerena nasab. Adapun wanita-wanita yang haram dinikahi oleh seorang laki-laki yang disusui oleh seorang wanita tersebut adalah sebagai berikut: ${ }^{12}$

1. anita yang menyusinya dan Ibunnya (karena mereka termasuk ibu-ibunya)

2. Ibu dari ibu susuan, karena statusnya sebagai nenek dari anak yang disusui.
3. Ibu dari suami ibu susuan (mertua ibu susuan ), karena ia juga nenek bagi anak yang disusui.

4. Saudara perempuan ibu susu, karena dia menjadi bibi baginya.

5. Saudara perempuan dari suami ibu susuan.

6. Anak keturunan ibu susuan, baikdaripihak laki-laki maupun perempuan (cucu dan seterusnya), karena mereka adalah saudara satu susuan, begitu juga dengan anak-anak mereka.

7. Saudara perempuan satu susuan, baik dari pihak ayah dan ibu susuan maupun dari salah satunya.

Rada'ah aatau penyusuan yang menjadikan haram pernikahan ini adalah penyusuan yang sempurna, yaitu penyususan sesorang anak kepada seorang perempuan dengan menyedot air susu dari putting susu perempuan tersebut sampai sianak merasa puas dan kenyang) dan melepaskannnya sendiri, bukan lepas kerena ada sesuatu yang memaksanya.Bila anak itu hanya mengisap dengan sekli atau dua hisapan saja maka persusuan seperti ini tidaklah menjadikan haram pernikahan. Dalam suatu riwayat Aisyah menyatakan, ${ }^{13}$ 
"menyusui dengan satu atau dua kali hisapan, tidak mengharamkan pernikahan.

Dengan demikian dapat dipahami bahwa menyusu dalam kadar yang sedikit tanpa menghilangkan rasa lapar sianak maka menurut hadis yang diriwayatkan Aisyah di atas tiadaklah menjadikan hukum haram terjadi pernikahan sebagaimana disebutkan terdahulu. Namun demikian ada tiga pendapat yang masyhur mengenai jumlah penyusuan yang menyebabkan haramuntuk dinikahi, sebagai berikut: ${ }^{14}$

1. Banyak atau sedikitnya susu yang diisp oleh bayi, menjadikan haram pernikahan. Dan pendapat ini adalah pendapat jumhur ulama'. Pendapat ini berdasarkan keumuman makna kata menyususi yang terdapat dalam ayat alQur'an ${ }^{15}$ dan hadis Nabi ${ }^{16}$, Dalam sebuah hadis juga Imam Bukhari dan Muslim meriwayatkan bahwa uqbah bin Harits berkata "aku telah menikah dengan ummu Yahya binti Abu lahab. Kemudian datang seorang budak perempuan yang berkulit hitam, lalu dia berkata Aku telah menyususi kalian berdua. Kemudian mengatakannnya kepada Rasulullah. Atas apa yang terjadi. Rasulullah saw. Kemudian bersabda, "Mau bagaimana lagi dia telah mengatakan yang seperti itu, maka ceraikanlah dia". ${ }^{17}$ Dalam hadis ini Nabi tidak menyatakan berapa kali susuan yang mengharamkan pernikahan, dengan demikian dipahami bahwa hadis diatas tidak menyatakan ketentuan khusus berapa kali susuan yang mengharamkan pernikahan tersebut. Tetapi apabila terjadi persusuan baik dalam jumlah sedikit atau banyak (berkali-kali), maka mengharamkan pernikahan, karena yang menjadi inti adalah persusuan itu sendiri, bukan banyak sedikitnya atau sering tidaknya persusuan tersebut.

2. Diharamkan karena tiga kali penyususan atau lebih.Pendapat ini berdasarkan hadis Nabi yang mengatakan "Tidak diharamkan karena sekali atau dua kali hisapan, dan hadis Ummu Fadhal yang mengatakan bahwa seorang badui menemui Nabi yang menceritakan tentang isterinya. ${ }^{18}$

3. Haram karena lima kali (susuan) isapan atau lebih dalam waktu yang berbedabeda.Hal di atas berdasarkan hadis Nabi dari Aisyah bin Abu Bakar, dia berkata: Dalam al-Qur'an disebutkan bahwa d iantara hal yang mengharamkan pernikahan adalah sepuluh kalisusuan, kemudian ayat ini dihapus dan diganti dengan lima kali susuan. Ketika Rasulullah sudah wafat, ayat mengenai sepuluhkali susuan itulah yang banyak 
dibaca dan dijadikan pedoman bagi masyarakat. ${ }^{19}$ Pendapat ketiga ini dapat dipahami bahwa adanya haram terjadinya pernikahan apabila penyususn tersebut mencapai lima kali atau lebih.

Dari ketiga pendapat di atas pada prinsipnya bahwa terjadinya penyusuan terhadap anak memberi implikasi akan keharaman menikah karena telah terjadi hubungan muhrim, hanya saja hitungan penyususan tersebut yang ada perbedaan. Hubungan muhrim yang terjadi dari orangyang menyusui, bagaimanapun caranya dapat menghilangkan rasa lapa seorang anak, dan membantu pertumbuhan anak. Dengan demikian bagaimanapun cara air susu sampai kepada anak sudah menjadikannya bagian dari muhrim perempuan yang menyusui anak tersebut.

Secara Yuridis masalah pemberian ASI atau menyusui oleh seorang perempuan kepada anaknya ditujukan adalah untuk menjamin pemenuhan hak seorang bayi, memberikan perlindungan kepada ibu, meningkatkan peran dan dukungan keluarga, masyarakat dan pemirintah, oleh kerena itu di Indonesia dituangkan dalam Peraturan Pemerintah (PP) Nomor 33 tahun 2012 tentang pemberian asi ekslusif, ${ }^{20} \mathrm{PP}$ ini telah diundangkan dan diberlakukan pada tanggal 1 Maret 2012. PP ini membicarakan tentang pemberian Asi kepada anak (bayi) secara umum, namun belum membicarakan implikasi dari penyusuan (radha'ah) terhadap anak bila yang menyusui anak itu bukan ibu dari anak tersebut, terutama implikasi terhadap perkawinan atau pernikahan.

Dalam Peraturan perundangundangan perkawinan bab II tentang syaratsyarat perkawinan pada pasal (8) poin (c) dinyatakan larangan perkawinan karena hubungan persusuan..$^{21}$ Dalam Kompilasi Hukum Islam di Indonesia bab VI pasal 39 tentang larangan kawin poin 3 adalah karena pertalian sesusuan: ${ }^{22}$

1. Dengan wanita yang menyusuinya dan seterusnya menurut garis lurus ke atas.

2. Dengan seorang wanita sesusuan dan seterusnya menurut garis lurus ke bawah.

3. Dengan seorang wanita saudara sesusuan, dan kemenakan sesusuan ke bawah

4. Dengan seorang wanita bibi sesusuan dan nenek bibi sesusuan ke atas.

5. Dengan anak yang disusui oleh isterinya dan keturunannya.

\section{Tinjauan Radha'ah Secara Psikologis}

Perkembangan manusia secara psikologis dijelaskan oleh al-Qur'an dan al- 
sunnah, bahwa siklus perkembangan manusia sejak masih berupa sel telur, embrio dalam rahim, sampai episode terakhir di muka bumi, manusia dicftakan dari air yang hina (sperma), melalui perjalanan waktu lalu berubah menjadi segumpal darah, dan berubah menjadi segumpal daging. ${ }^{23}$

Proses penyusuan, dikatakan proses yang paling berpengaruh dalam pembentukan jati diri seorang anak manusia, anak sangat dengan ASI wanita yang menyusuinya, akhlaknya melalui air susu yang diminumnya. Oleh karena itu semestinya memilih wanita yang baik akhlaknya dari komunitas yang baik. ${ }^{24} \mathrm{Al}$-ghazali menyatakan, Air Susu Ibu yang keluar dari makanan haram tidak ada berkahnya, jika terserap olah anak kecil, maka jasmaninya ternoda dengan materi yang buruk, akhirnya perangainya cenderung kepada tindakan-tindakan yang buruk. ${ }^{25}$

Dari pernyataan-pernyataan di atas menggambarkan betapa pengaruh psikologis seorang perempuan yang menyusui seorang anak dalam pembentukan pribadi baik buruknya seorang anak. Dengan demikian dapat dipahami bahwa, seorang wanita sholihah yang menyusui seorang anak, secara psikologis dapat membentuk kepribadian anak menjadi anak yang sholeh dan baik, karena dalam proses penyusuan itu mengalir tali kasih sayang, cinta, perlindungan, pada jiwa anak dari seorang ibu, di samping memenuhi kebutuhan energi si anak (bayi).

\section{Tinjauan Radha'ah secara Sosiologis dan}

\section{Ekonomis}

Pada masyarakat Arab penyusuan anak diserah kepada orang lain adalah hal yang biasa, Nabi Muhammad sendiri dalam sejarah dikatakan bahwa ia semenjak umur satu minggu diserahkan penyusuannya kepada seorang perempuan Arab Badui Halimatusa'diyah, dan ini telah menjadi tradisi masyarakat Arab. Di belahan dunia lainnnya terrutama di Indonesia sebelum abad ke- 20 hampir setiap bayi itu disusui oleh ibunya, karena tidak ada pilihan lain, namun pada awal abad ke-20 (tahun 1900-an) terjadi perubahan nilai tentang menyusui bayi, seiring industrialisasi dan modernisasi. ${ }^{26}$ Adanya tuntutan hak-hak perempuan di bidang politik dan ekonomi. Tuntutan-tuntutan tersebut membuat nilai-nilai menyusui mengalami pergeseran.

Pergeseran tersebut membawa anggapan menyusui adalah ketinggalan zaman (kuno), mengikat, bentuk perbudakan, cara makan orang yang miskin yang tidak dapat membeli susu formula.Maka roti dan menyusui bayi lewat botol dianggap adalah yang terbaik dan sebagai tanda perempuan dari kalangan menengah modern. Sebenarnya pemberian ASI kepada bayi dipengaruhi oleh banyak faktor, diantaranya faktor sosial budaya, pengetahuan akan pentingnya ASI, dukungan jajaran kesehatan, keluarga, 
kesehatan, waktu tersita karena kerja yang tidak kala pentingnya adalah pemakaian susu formula.

Secara Ekonomis, pandangan pertama: bagi ibu yang bekerja, maka penyerahan penyusuan kepada orang lain atau perempuan lain merupakan hal yang mempermudah dan menolong pekerjaannnya, walau disisilain ia harus mengeluarkan dana untuk membayar perempuan yang menyusui anaknya. Pandangan kedua: bagi seorang ibu yang menyerahkan penyusuan anaknya kepada perempuan lain dikarenakanada faktor yang membuat ia tidak dapat menyusui anaknya, seperti tidak mempunyai air susu, ada suatu penyakit yang tidak membolehkannnya menyusui anaknya karena takut menularkan sakit tersebut, maka hal ini akan sangat memberatkan dan menambah biaya atau beban ekonomi.

Di lain fihak, perempuan yang menyusui anak orang lain, maka ia akan menerima upah dari orang yang menyusukan anak, maka kegiatan menyusui anak orang lain yang diserahkan kepada seorang perempuan untuk menyusuinya menjadi suatu lapangan kerja yang dapat menambah penghasilan. Hanya saja untuk di Indonesia, kegiatan menyusukan anak kepada orang lain baik dengan cara mengupah ataupun tidak, itu jarang dilakukan, di Indonesia cara yang demikian belum membudaya. ${ }^{27}$ Orang tua lebih baik mempercayakan penyusuan anak dengan alternatif pengganti dengan susu formula yang banyak beredar di pasaran, di samping itu di Indonesia belum ada yang namanya bank susu.

\section{Penutup}

1. Radaah adalah penyusuan anak atau bayi yang diserahkan kepada perempuan lain yang bukan ibunya, yang mengakibatkan hukum mahram antara ibu menyusui serta anak-anaknya dengan anak yang disusuinya.

2. Radaah diperbolehkan oleh Islam, sesuai aqad atau perjanjian antara orang tua anak dengan perempuan yang menyusuinya.

3. Secara budaya, maka di Indonesia tidak ada, karena kalaupun orang tua tidak dapat menyusui anaknya karena sesuatu hal, maka alternatif yang diambil adalah memberi anaknya dengan susu formula. Adapun Radaah ini biasa di lakukan oleh orang Arab.

\section{Endnote}

'Ibnu Qoyyim, Tuhfatul Maudud bi alAhkami al-Maulud, (Darul baya, T.tp, 1407H), Cet II, h. 171. Lihat juga, F.J/ Monks,at. All, Psikologi perkembangan: Pengantar dalam berbagai bagian, (Yogyakarta: Gadjah Mada University Press, 1999), h. 70-78, lihat, John W. Santrok: LifeSpan Development (University of Texsas at Dallas), Perkembangan Masa Hidup, (Jakarta: Erlangga, 2002), h. 143-148. 
${ }^{2}$ Q.S. al-Baqoroh: 233. Artinya "Para ibu hendaklah menyususkan anakanaknya selama dua tahun penuh, yaitu bagi yang ingin menyempurnakan penyusuan". Fase ini dianggab sangat penting karena pengaruh ekternal setelah dari rahim seorang ibu mulai bersinggungan dengan si bayi, sebagaimana Ibnu Qoyyim menyatakan: Janin yang baru saja meninggalkan rahim ibu, telah melepaskan diri dari ruangan yang biasa meliputinya dalam seluruh kondisi, hanya dalam satu waktu saja. Lebih lanjut dinyatakan bahwa proses menyusui adalah yang sangat berpengaruh dalam pembentukan jati diri anak. Lihat, Ibnul Qoyyim, ibid.

${ }^{3}$ Banyak faktor yang menyebabkan terjadinya radha 'ah tersebut, baik dari faktor sosial budaya maupun dari faktor dari dalam diri ibu itu sendiri.

${ }^{4} \mathrm{Abu}$ Qosim al-Husain bin Muhammad bin al-Mufadhal, Mu'jam Mufradat al-Fadz al-Qur'an, (Beirut: Dar al-Kutb al-Ilmiyah, 2004M/1425H), h. 222, Lihat juga Q.S: alBaqoroh: 233.

${ }^{5}$ Ibid.

${ }^{6} \mathrm{I} b i b$

${ }^{7}$ Lebih lanjut tentang persusuan lihat Sayyid Sabiq, Figh al-Sunnah, (Dar al-Fath lil I'lamy al-Araby, 2011M/1432H), h. 296-315

${ }^{8}$ Lihat Wahbah al-Zuhaili, Fiqh alIslami wa adillatuhu, (Damaskus: dar al-fikr, 2007/1428 ), Juz X, h. 45

9"Ibu-ibumu yang menyusui kamu, dan saudara perempuan sepersusuan", Departemen Agama, Al-Qur'an dan Terjemahannnya (Bandung; Sinar Baru Algensindo, 2007), h. 157

${ }^{10}$ al-Bukhari, Shahih al-bukhari, (Indonesia: Mktabah Dahlan, 1992), no 2645, Muslm, Shahih Muslim, (Indonesia, Maktabah dahlan, 1992), no.1447

${ }^{11}$ ibid.,

${ }^{12}$ Sayyid Sabiq, Fiqh Sunnnah, (Dar Fath lil I'lami: al-Arabiy), Terjemahan Abdurrohim dan Masruhin, Figh Sunnah, (Cakrawala Publising: Jakarta), 2011M/ 1432H, h. 297, lihat juga al-Badai'I, (2/4), al Mughni (571/6), al-Muhalla (2/10), Jami' Ahkam al-Nisa' (47/3).
${ }^{13}$ Imam Muslim, Shahih Muslim, (Maktabah: Kairo), Jilid.II, h. 1072 no. 20, dalam ar-radaah, bab fi al-mashashah awmashshatani: La tuharrimul mashohatu wal mashotaaniy, Lihat juda Imam Abi daud, Sunan Abi Daud (Maktabah: Kairo), Jilid II, h. 551, no.2063, pada bab Nikah pada bab" hal Yuharrimu duna Khamsi Radaah", Imam Turmuzi, Sunan al-Turmuzi, (Maktabah: Kairo), Jilid III, h. 446, no.1150, dalam bab" ar-rada, ma jaah La tuharrim al-Mashshah wa la a'-Mashshslani". Imam al-Darimi, Sunan al-Darimi, (Maktabah: Kairo), Jilid II, h. 157, dalam kitab "Nikah", bab "Kam radaatan Tuharrim.

${ }^{14}$ Sayyid sabiq, Op. cit; h. 298, lihat juga Abu malik Kamal bin as-Sayyid Salim, Shahih Fiqh as-Sunnah, terjemahan Abu ihsan Al-Atsari, Amir Hamzah: Shahih Fiqh Sunnah (Pustaka al-Tazkia, 2006), h. 110-112.

${ }^{15}$ Q.S. al-Nisa': 23

${ }^{16}$ Innama radhaatu minal majaah" sesungguhnya penyusuan itu karena kelaparan". Imam al-bukhari, Shahih alBukhari, (Jakarta: Maktabah Dahlan), hadis 5102, Imam Muslim, shahih Muslim (Jakarta: Maktabah Dahlan),. hadis 1455., selanjutnya hadis "Yuharrimu min al-radhaah ma yuharrimu min nasab", diharamkan karena penyususn apa yang diharamkan karena nasab. Lihat Imam Bukhari hadis 264, Imam Muslim hadis 1447.

${ }^{17}$ Bukhari, Ibid., Jilid VII, h. 13, dalam kitab al-Nikah, bab Syahadah al-Murdi'ah, Jilid III, h. 664 dalam kitab asy-Syahadat, bab iza Syahida Syahidun aw syuhudun bi Sya'in, Imam Turmuzi, Op.Cit., Jilid III. h. 44 dalam kitab Rada'ah bab ma jaa fi Syahadati al-Mar'ah. Imam Abi Daud, $O p$. Cit., Jilid IV, h. 37-38, dalam kitab al-Aqdiyah babaly-Syahadah fi al-Radha'. Imam alNasai, Sunan al-nasai, (Jakarta: Maktabah Dahlan, t.th), Jilid VI, h. 109 dalam kitab Nikah, bab al-Syahadah fi Radaa', Ahmad bin Hanbal, Musnad Ahmad bin Hanbal, Jilid IV, h. 7 -8, 384, Imam al-Darimi, Sunan aldarimi, Jilid II, h. 80 no. 2260. Dalam kitab Nikah bab Syahadati al-mar'ah alWahidah li ar-radha' 
${ }^{18}$ Muslim, Op. Cit., h. 1451, 2659, Turmuzi, Op. cit., h. 1150, Abu Dawud, Op. cit., h. 2063, a-Nasa'i, Op. Cit., h. 101, dalam riwayat tersebut diceritakan bahwa seorang Badui menemui Rasulullah dan berkata: Sesungguhnya aku memiliki seorang isteri, lalu aku menikah lagi dengan wanita lain, isteri yang pertama mengklaim ia telah menyusui isteriku yang baru sekali atau dua kali susuan", Nabi berkata: Tidak menjadi haram karena sekali atau dua kali hisapan.

${ }^{19}$ Muslim, Ibid., Jilid. II , h. 1075, Abu Dawud, Ibid., Jilid II, h. 551, al-Nasai' I, Ibid., Jilid VI, h. 100., al-Turmuzi,Op. Cit., Jilid III,h. 477, al-Darimi, Op. Cit., Jilid.II, h. 80.

${ }^{20}$ Sebagaimana ditulis oleh Selamat Riyadi dalam Tinjauan Terhadap Peraturan pemerintah tentang Pemberian Air Susus Ibu Eksklusif, Perspektif Regulasi (diakses/ 29/10/2013), PP ini terdiri dari 10 bab, 43 pasal 55 ayat dan mengatur 7 hal pokok yaitu:1) Tanggung jawab pemerintah, pemerintah daerah provinsi, dan pemerintah daerah kabupaten/kota 2) Air Susu Ibu, 3) Penggunaan susu formula dan produk lainnnya, 4) tempat kerja dan tempat sarana umum, 5) dukungan masyrakat, 6) pendanaan, 7) Pembinaan dan pengawasan. PP ini juga lahir sesuai dengan amanat tentang UndangUndang Kesehatan Nomor 36 tahun 2009 tentang Kesehatan.

${ }^{21}$ Dalam pasal 8 ini disebutkan: "Perkawinan dilarang antara dua orang yang: Poin (c) berhubungan susuan, yaitu orang tua susuan, anak susuan, saudara susuan dan bibi/ paman susuan, lihat Direktorat jenderal
Bimbingan masyarakat Islam Departemen Agama republik indonesia, Himpunan Peraturan Perundang-undangan Perkawinan (t.tp: Jakarta), h.20.

${ }^{22}$ Direktorat Pembinaan Badan Peradilan Agama Direktorat Jenderal Pembinaan kelembagaan Agama Islam Departemen Agama RI, Kompilasi Hukum Islam Di Indonesia, (t.tp: Jakarta), h.27.

${ }^{23}$ Q.S, al-Mukmin: 67, Lihat juga alBukhari, Op. Cit., Jilid II, h. 424 (Kitab Bad'ul Wahyi, bab Zkir al-Malakah, nn. 3208, lihat Muslim, Op.Cit., Jilid IV, h. 2036 (Kitab alQadr, Kaifiyatul Adami fi Bathni Ummihi, no. 2643 ,

${ }^{24}$ Ibn Qoyyim, Loc. Cit.

${ }^{25} \mathrm{Al}$ - Ghazali, Ikhya' Ulumu alDin,(Maktabah al-Kohiroh, Mesir), Jilid III, h. 71

${ }^{26}$ Dalam era industialisasi dan modernisasi maka banya para ibu yang bekerja di luar rumah dengan menempuh jarak yang jauh dan waktu yang lama, maka ibu-ibu beralasan tidak ada waktu untuk menyusui, repot bayi tidak bisa dibawa ketempat kerja, harus pulang balik untuk menyusui, tidak adanya disediakan tempat atau ruangan menyusui, dan yang tidak kalah pentingnya begitu gencar dan banyaknya iklan susu formula sebagai alternatif pengganti ASI.

${ }^{27} \mathrm{Di}$ Indonesia budaya mengupah untuk menyusukan anak tidak ada, banyak faktor yang menjadikan demikian, perempuan Indonesia masih memegang prinsip bahwa yang harus menyusui anak adalah ibunya, kalaupun mereka bekerja dan tidak menyusui anaknya adalah karena terpaksa. 